Article

\title{
A New Method to Map Groundwater Table in Peatlands Using Unmanned Aerial Vehicles
}

\author{
Mir Mustafizur Rahman ${ }^{1, *}$ (D) , Gregory J. McDermid ${ }^{1}$ (D), Maria Strack ${ }^{2}$ and Julie Lovitt ${ }^{1}$ \\ 1 Department of Geography, University of Calgary, Calgary, AB T2N 1N4, Canada; \\ mcdermid@ucalgary.ca (G.J.M.); julie.lovitt@ucalgary.ca (J.L.) \\ 2 Department of Geography and Environmental Management, The University of Waterloo, \\ Waterloo, ON N2L 3G1, Canada; mstrack@uwaterloo.ca \\ * Correspondence: mmrahm@ucalgary.ca; Tel.: +1-403-220-8289
}

Received: 16 August 2017; Accepted: 13 October 2017; Published: 17 October 2017

\begin{abstract}
Groundwater level (GWL) and depth to water (DTW) are related metrics aimed at characterizing groundwater-table positions in peatlands, and two of the most common variables collected by researchers working in these ecosystems. While well-established field techniques exist for measuring GWL and DTW, they are generally difficult to scale. In this study, we present a novel workflow for mapping groundwater using orthophotography and photogrammetric point clouds acquired from unmanned aerial vehicles. Our approach takes advantage of the fact that pockets of surface water are normally abundant in peatlands, which we assume to be reflective of GWL in these porous, gently sloping environments. By first classifying surface water and then extracting a sample of water elevations, we can generate continuous models of GWL through interpolation. Estimates of DTW can then be obtained through additional efforts to characterize terrain. We demonstrate our methodology across a complex, 61-ha treed bog in northern Alberta, Canada. An independent accuracy assessment using 31 temporally coincident water-well measurements revealed accuracies (root mean square error) in the 20-cm range, though errors were concentrated in small upland pockets in the study area, and areas of dense tree covers. Model estimates in the open peatland areas were considerably better.
\end{abstract}

Keywords: UAV; photogrammetry; groundwater table; peatland; remote sensing; spatial interpolation

\section{Introduction}

Peatlands are terrestrial wetland environments where the net production of organic matter exceeds its decomposition rate, leading to the accumulation of partially decomposed vegetation known as peat [1]. Peatland ecosystems cover large portions of the northern hemisphere's Boreal/Taiga biome [2], and represent vast hydrological reserves, globally significant stores of soil carbon, and hotspots of biodiversity [3]. In peatlands, the position of groundwater table plays a key role in ecosystem functioning, controlling the hydrological flow direction/discharge, rates of peat accumulation, and the chemical processes governing nutrient cycling and greenhouse gas (GHG) flux [4-6]. While groundwater tables are commonly characterized as both ground-water level (GWL)—defined as the height of groundwater above mean sea level—and depth to water (DTW)—the depth to groundwater relative to local terrain level-the two metrics are clearly related. In this paper, we will use groundwater as a general term, but return ultimately to the more specific metrics as we proceed. Both variables, GWL and DTW, are key factors in understanding hydrological processes and estimating GHG $\left(\mathrm{CO}_{2}\right.$, $\mathrm{N}_{2} \mathrm{O}$ and $\mathrm{CH}_{4}$ ) emissions in peatlands, and are among the most commonly sought measurements for researchers working in these ecosystems [7].

While groundwater can be measured reliably in the field using piezometers and shallow monitoring wells $[8,9]$, these point-based techniques are difficult to scale due to the cost of instruments 
and installations $[10,11]$. In addition, the repeated measurements needed to monitor groundwater dynamics are often constrained by access to field personnel. The research reported in this paper was motivated by the desire to develop a strategy for measuring groundwater with remote sensing, in order to provide a means of generating reliable measurements repeatedly over large areas.

It is important to note that groundwater mapping is an unusual application for Earth-observing sensors, since the target-of-interest is not directly observable from the sky [12,13]. As a result, various methods have been developed aimed at proxy measures of groundwater in peatlands, such as plant water stress, vegetation composition and density, soil-moisture content, topographic features, and other indirect indicators. For example, Harris and Bryant [4] used Sphagnum-moss health as a proxy indicator of surface peat hydrology in Wales, with the authors observing a good correlation between remotely estimated Sphagnum water stress and field-measured volumetric moisture content. Similarly, Meingast et al. [14] used spectral indices as a proxy for near-surface moisture content and groundwater-table position in peatlands, based largely on vegetation response.

While proxy indicators of groundwater can be linked to field measurements to produce large-scale hydrological information (e.g., $[12,15,16])$, these approaches are constrained by a variety of confounding factors. For example, the response of vegetation to groundwater level will vary as a function of plant abundance, type, and size [17], and the presence of overstory canopies, which regularly obstruct the visibility of surface vegetation $[18,19]$. In addition, the use of proxy indicators requires analytical techniques (e.g., image classification) that are subject to inaccuracies [12,20] which may render these proxies unreliable.

One potential solution emerges from the observation that peatlands generally contain an abundance of small water bodies that are regularly visible on the surface. Since surface water is tightly linked to groundwater in peatlands, it should be possible to infer water-table levels through the mapping of surface water, under the assumption that peatlands are internally porous with flat or gently sloping water tables [21]. All that is required in this scenario is a remote-sensing technology that is capable of mapping small water features reliably, and a strategy for extracting their elevations accurately. Using this principle, we can obtain a direct measurement of GWL in locations where it is visible, and generate continuous-surface estimates over large areas through interpolation. Converting GWL to DTW would be further possible through additional mapping of detailed surface terrain (e.g., [19]) and simple GIS operations. What has been lacking, until recently, is a platform capable of delivering the appropriate remote-sensing data.

Unmanned aerial vehicles (UAVs) provide imagery at extraordinarily high spatial resolutions and user-defined time intervals, and can be used to generate dense three-dimensional point clouds using modern structure-from-motion (SfM) workflows (e.g., [22-27]). In this paper, we present a novel method for characterizing groundwater and mapping both GWL and DTW using two secondary UAV-derived data products: orthophotography and photogrammetric point clouds. We demonstrate and test our approach in a treed-bog peatland in northern Alberta, Canada.

\section{Materials and Methods}

\subsection{Study Area}

Our 61-ha study area is located in a treed bog about $40 \mathrm{~km}$ northeast of Peace River, Alberta, $\left(56^{\circ} 21^{\prime} 50^{\prime \prime} \mathrm{N}, 116^{\circ} 47^{\prime} 80^{\prime \prime} \mathrm{W}\right.$; Figure 1). The site is typical of forested bogs throughout western North America, where the climate is generally dry enough to permit the growth of trees in these types of wetlands [28]. In our study site, black spruce (Picea mariana) is the dominant tree species, with shrubby understory of Labrador tea (Rhododendron groelandicum), lingonberry (Vaccinium vitis-idaea), and cranberry (Oxycoccus microcarpus). The ground layer is comprised primarily of various Sphagnum species. The water table is generally close to the surface, and visible at various points across the study area, including a large pond in the south and numerous smaller features throughout (Figure 1). The study area also contains numerous linear disturbances, including a mineral-filled road that roughly 
bisects the site from north to south. Smaller features, including seismic lines (linear corridors used for sub-surface mapping and petroleum exploration) and a pipeline, are also visible in Figure 1.

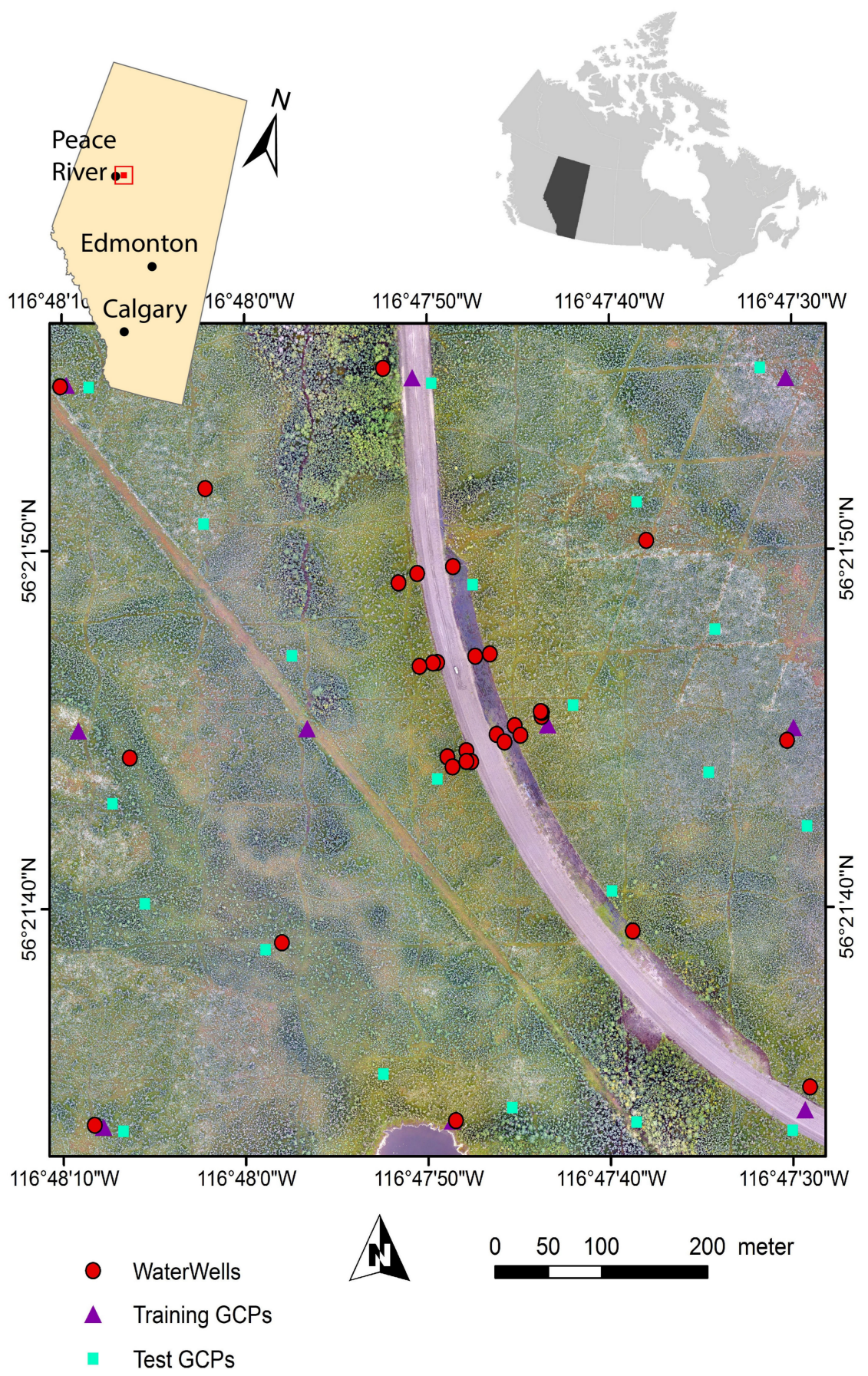

Figure 1. Location and overview of the study area in northern Alberta, Canada.

\subsection{Data Sets}

Three types of data were used in this study: (i) remote sensing data, from which orthophotography and photogrammetric point clouds were derived; (ii) well sites, from which groundwater measurements (GWL and DTW) were made; and, (iii) ground-control points (GCPs) that we used to integrate the fieldand remote-sensing measurements. All three data sets are described below. 


\subsubsection{Remote Sensing Data}

We used an Aeryon HDZoom30 20-megapixel optical camera on board an Aeryon Skyranger UAV to collect remote-sensing data for this project. The images were captured in an automatic mode (to enable the camera parameter to automatically be adjusted according to the prevailing environmental conditions) and with a nadir view angle. The site was flown on 31 August 2016 using flight lines designed to deliver $2 \mathrm{~cm}$ ground-sample distance with a minimum $80 \%$ endlap and $60 \%$ sidelap. Images were acquired under stable, diffuse-light conditions in order to minimize shadows in the scene. Flying height was $110 \mathrm{~m}$ altitude (above ground level) and flight speed was $4 \mathrm{~m} / \mathrm{s}$. Winds were low $(<3 \mathrm{~m} / \mathrm{s})$, minimizing the potential for vegetation movement that can interfere with the SfM workflow and therefore quality of secondary data products. A total of 851 photos were captured and their center-point coordinates (from on-board GPS) were recorded.

\subsubsection{Groundwater Measurements}

We installed 31 water wells around the study site (Figure 1): 17 along the access road and another 14 at random locations elsewhere. Wells were constructed using $1.5 \mathrm{~m}$-long, $2.5 \mathrm{~cm}$-diameter PVC pipe with holes drilled along their entire length to allow water infiltration. The wells were pushed into pre-drilled holes in the peat created with a hand auger. The longitude $(X)$, latitude $(Y)$, and elevation (Z) of the wells were recorded with a Trimble R8 Real time Kinematic (RTK) GPS system ( $10 \mathrm{~mm}$ vertical accuracy and $\sim 20 \mathrm{~mm}$ horizontal accuracy). Groundwater levels were measured across the network of wells within $24 \mathrm{~h}$ of UAV flights on 31 August 2016. Measurements were obtained using a measuring tape attached to a blowpipe. The blowpipe was used to identify water level within the well, and the measuring tape was used to record the depth. The depth to groundwater measured from the reference wells ranged between -17 (negative DTW values represent sites inundated with water) to $+58 \mathrm{~cm}$.

\subsubsection{Ground Control Points}

Ten ground control points (GCPs) were installed systematically across the study site for georeferencing purposes (Figure 1). An additional 20 randomly located GCPs were also installed (Figure 1) across the site to assess the accuracy of the secondary remote sensing data products (orthophotography and photogrammetric point clouds). The $X$ and $Y$ accuracy (RMSE) of the secondary products were reported as sub-centimeter, and the $Z$ accuracy was reported as $21 \mathrm{~cm}$.

\subsection{Workflow}

An overview of our workflow for mapping groundwater from UAV data is provided in Figure 2, and described more fully in subsequent sections. To summarize, we first identified pockets of open water across the study area through classification, using RGB orthophotography and a canopy height model (extracted from photogrammetric point cloud) as inputs. We then extracted point elevations from within these water bodies to create a sample of visible GWL. These samples were then interpolated to generate a full GWL surface. In order to transform GWL to DTW, we subtracted the GWL surface from a detailed digital terrain model (again, extracted from the photogrammetric point cloud). 


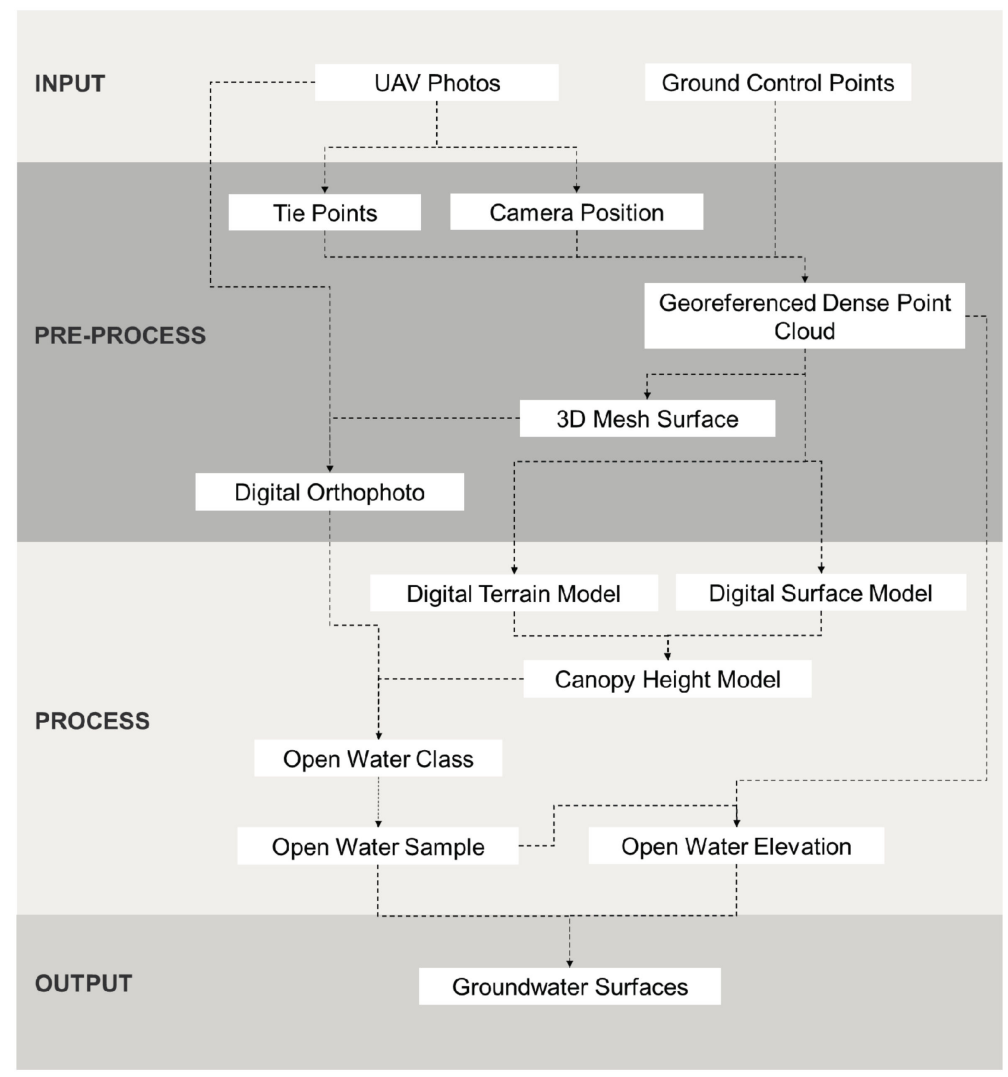

Figure 2. Workflow for mapping groundwater using unmanned aerial vehicle (UAV) orthophotography and photogrammetric point clouds.

\subsubsection{Pre-Processing}

Agisoft Photoscan was used to generate photogrammetric point clouds and digital orthophototography (RGB) from the input UAV imagery and GCPs. Photoscan (a commercial software package) first aligns the photos by searching for common reference points among overlapping photos. The software then uses $X, Y$, and $Z$ values from each ground control point, along with the camera positions (recorded automatically during the data collection), to generate and geolocate a dense point cloud. Next, the software builds a mesh that represents the three-dimensional (3D) surface of the study area, based on the point cloud. Finally, the mesh and associated RGB values from the photos are used to create digital orthophotography. The orthophoto was produced at $3 \mathrm{~cm}$ spatial resolution and the point density of the dense point cloud was reported as $191.81 \mathrm{pts} / \mathrm{m}^{2}$.

We acknowledge the work of previous researchers (e.g., [29]) who warned about the potential for systematic errors in SfM-based digital elevation models, which can arise from radial lens distortion in consumer-grade cameras mounted vertically on UAVs, and become expressed as vertical 'doming' in elevation-model products. We performed extensive validation of the underlying SfM-derived terrain models used in this work using 678 ground points surveyed in the field (see [19] for details), and found no evidence of such distortion. As such, our experience with the SfM workflow for terrain modeling is in line with recent authors (e.g., [30,31]) who reported satisfactory vertical accuracies without the need for supplementary mitigation.

A digital surface model (DSM) and a digital terrain model (DTM) were produced from the photogrammetric point cloud. The complete workflow of obtaining DSM and DTM from point cloud was recently published [19]. In summary, the point cloud (all points) were used to produce a DSM in ArcMap using LAS to Raster tool at $3 \mathrm{~cm}$ spatial resolution (to match the resolution of the orthophototography). Given the density of the points $\left(191.81 \mathrm{pts} / \mathrm{m}^{2}\right)$ a nearest-neighbor interpolation method was used to create the DSM. Then, ground points were extracted from all of the points using a 
combination of LAStools and Cloud Compare software. We first used LAStools to perform the initial preprocessing, including preliminary noise filtering and tiling. We then performed additional noise filtering using the statistical-outlier removal tool in Cloud Compare. Finally, we classified the ground points and manually removed the remaining noise (extreme high or low points) using LAStools. The point density of the classified ground points was $84.68 \mathrm{pts} / \mathrm{m}^{2}$. These ground points were then processed in ArcMap to produce the terrain model (DTM). A linear-triangulation method of interpolation was used in this case, and the output resolution was again set to $3 \mathrm{~cm}$. Finally, a canopy height model (CHM) was obtained by subtracting the DTM from the DSM. The orthophotography, DTM, and CHM were the main secondary data products used in further processing.

\subsubsection{Extracting Open Water}

We classified open water using ENVI (a commercial software package), with the orthophotography and CHM providing inputs. We used an object-based (segmentation) scheme [32] and a simple decision tree (Figure 3) to arrive at a final water classification. First, we separated ground from non-ground objects on the basis of mean canopy height, with a threshold of $0.1 \mathrm{~m}$. Ground objects were further divided into vegetated and non-vegetated objects using a green/red ratio, with a threshold of 1.1. Finally, non-vegetated objects were divided into bare soil and open water using an example-based (supervised) classification. This was performed by manually selecting 60 training objects (examples) from each class (open water and bare soil) that were used by the software (ENVI) to identify similar features within the image and assign classes to them. We chose a conservative approach to open-water classification in order to obtain maximum user's accuracy of the water class. The accuracy was assessed using 140 randomly selected sample points (70 water, and 70 others). While the overall classification accuracy was just moderate (79\% with a kappa of 0.63$)$, the open water class had only $4 \%$ errors of commission, meaning that we had high confidence in objects that were classified as water.

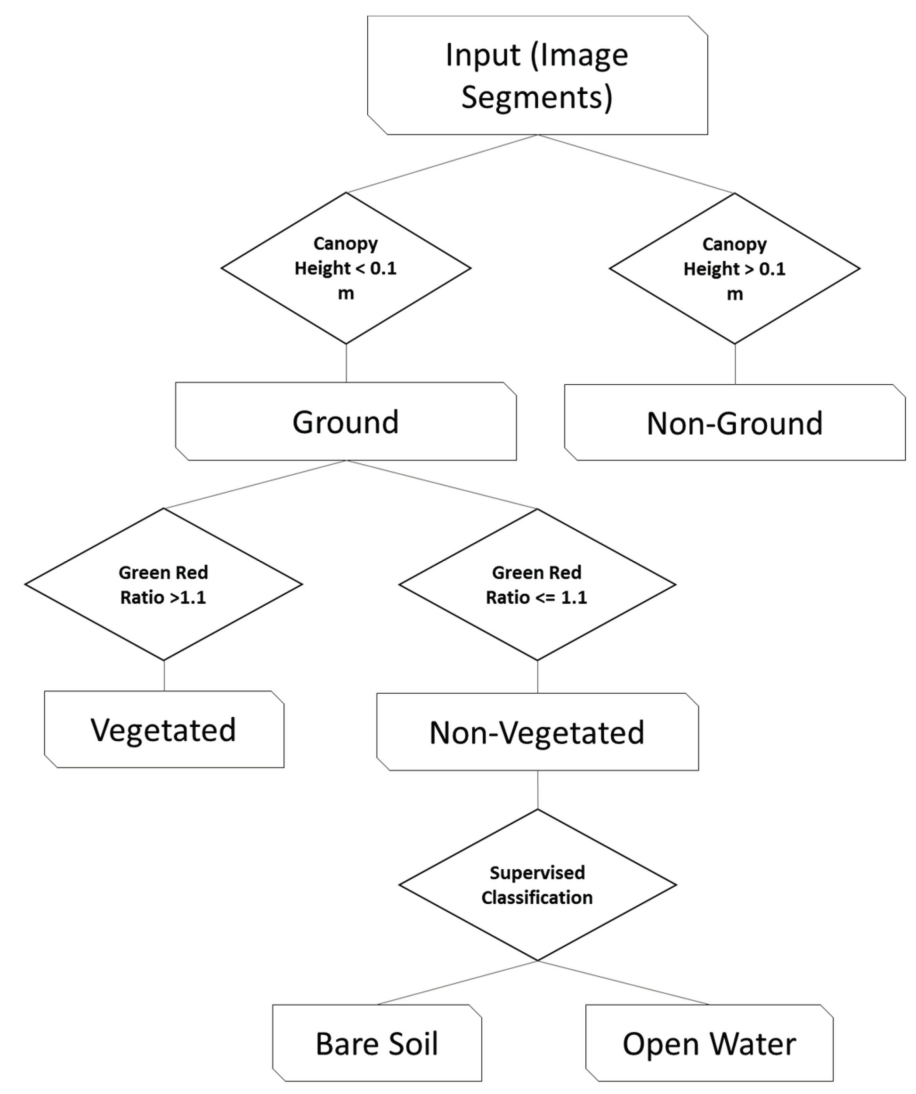

Figure 3. Object-based, decision-tree classification scheme to extract open water. 


\subsubsection{Sampling Open Water}

The open-water objects obtained through classification were assumed to reflect the level of groundwater across the study area at the time of image acquisition, but converting these features into continuous surfaces required interpolation. Previous experience [33] has shown that it is improper to use only the center-point of objects for interpolation, since large, long, and irregularly shaped water bodies might be underrepresented. Thus, we developed a spatially explicit sampling strategy, where one sample point per $50 \mathrm{~m}^{2}$ was selected to represent the elevation of the water table in that cell. This was done by tessellating the study area into $50 \mathrm{~m}^{2}$ cells, and selecting one water-sample point - the point with the median water-elevation value-from each cell. In this manner, a total number of 214 final groundwater samples were generated. Figure 4 shows examples of open water from a few locations in the study site.
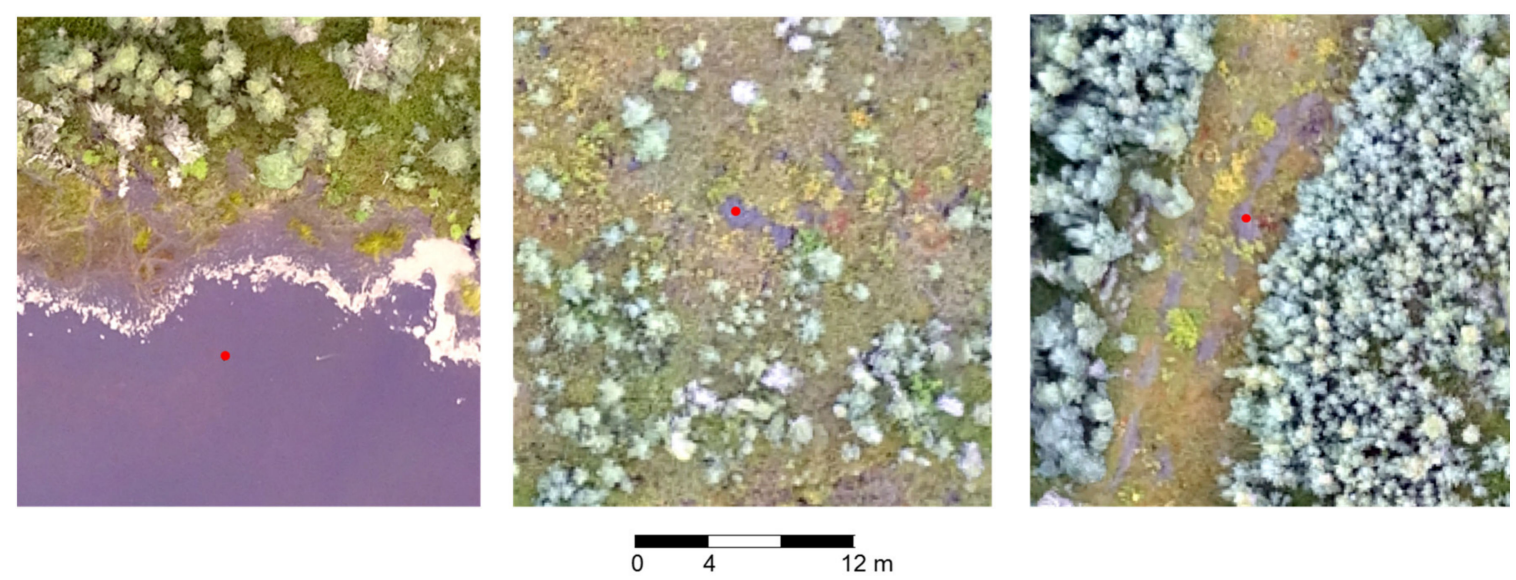

Figure 4. Examples of samples (red points) in open water (blue) from across the study area. In order to reduce the bias of using object center points for interpolation, we selected on sample point per $50-\mathrm{m}^{2}$ section to represent water level.

\subsubsection{Creating Ground-Water-Level and Depth-to-Water Surfaces}

The elevations of the final samples were interpolated using ordinary kriging to generate a GWL surface. We used ordinary kriging (type: ordinary; variogram: semivariogram; neighbors to include: 2-12; lag size: 57.48; nugget: 0.034; partial sill: 0.39; range: 460; and anisotropy: none) since it is generally regarded as the most common and reliable interpolation technique in the hydrology and environmental-studies literature [34-38]. The GWL surface was then subtracted from DTM to obtain a DTW surface.

\subsection{Validation}

We evaluated the quality of the GWL and DTW surfaces in two ways. First, we extracted DTW from the surface at the 31 field-sample (water well) locations and compared them with the field data using root-mean-square-error (RMSE) and other basic statistics. Second, we generated an error-distribution map by interpolating the absolute error at each reference point.

\section{Results}

The resulting GWL surface, representing the predicted elevation of the groundwater table in meters above mean sea level (m a.s.l.) is shown in Figure 5. Our estimates show groundwater to vary from 620 to $624 \mathrm{~m}$ a.s.l. across the study area, with the water table sloping generally from east to west. Figure 6 shows the predicted DTW surface, generated by subtracting the GWL surface from the detailed DTM of the study area. The microtopographic features (hummocks and hollows) that characterize natural peatlands are clearly visible, creating small variations in DTW. The impacts of 
the access road—high immediate DTW levels with inundated areas on the up-slope side-are readily apparent, as are the effects of small linear features (seismic lines and pipeline), which create low DTW values and ponding through the flattening of microtopography. The densely treed upland areas reveal generally high DTW values, in addition to interpolation noise caused by errors in the DTM. Photogrammetric point clouds are hindered by dense vegetation [19], reducing the effectiveness of our approach in these areas.

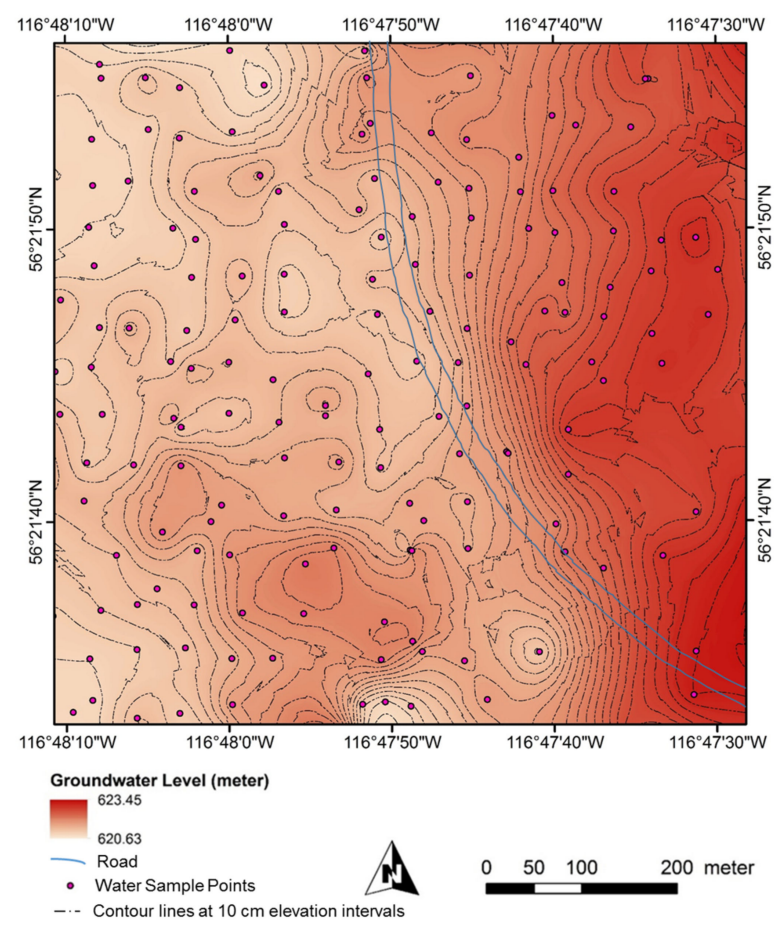

Figure 5. Predicted ground-water level across the study area.

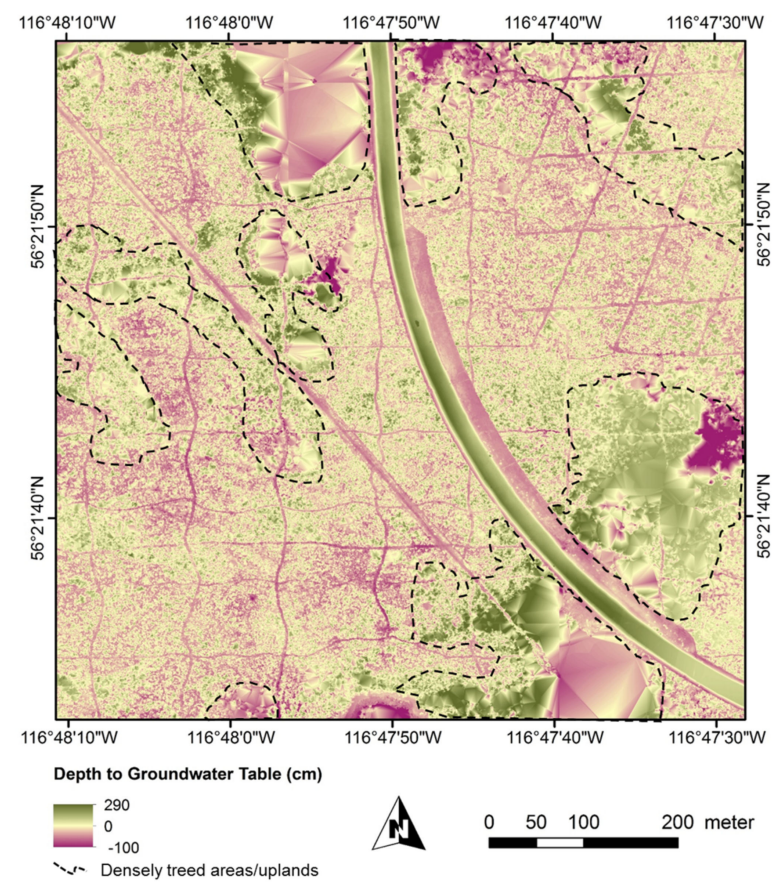

Figure 6. Predicted depth to groundwater table in the study area, where shades of green represent positive depth and shades of purple indicates negative depth (i.e., inundation). 
The results of the quantitative validation, derived from 31 independent, temporally coincident water-well observations, are summarized in Table 1. The accuracy of the GWL surface ranged from 0.6 to $50.5 \mathrm{~cm}$, with an RMSE of $22.0 \mathrm{~cm}$. The negative mean error $(-0.9 \mathrm{~cm})$ reveals a slight overestimation of the groundwater surface overall. Converting GWL to DTW does little to change the overall RMSE $(20.3 \mathrm{~cm})$, though the maximum observed absolute error increased to $65.3 \mathrm{~cm}$, and mean error increased to $-7.0 \mathrm{~cm}$. A scatterplot (Figure 7) between field-measured (water well) DTW and model-produced DTW reveals moderate positive correlation (Pearson's $r=0.40$ ). From the plot, it can also be concluded that we estimate WT at or slightly below the surface systematically at sites that are inundated (i.e., negative DTW). This makes sense, as the technique cannot reliably reach the terrain in flooded areas and may mistake the water surface as the ground in the DTM. However, this does not have any impact on the predicted GWL surface.

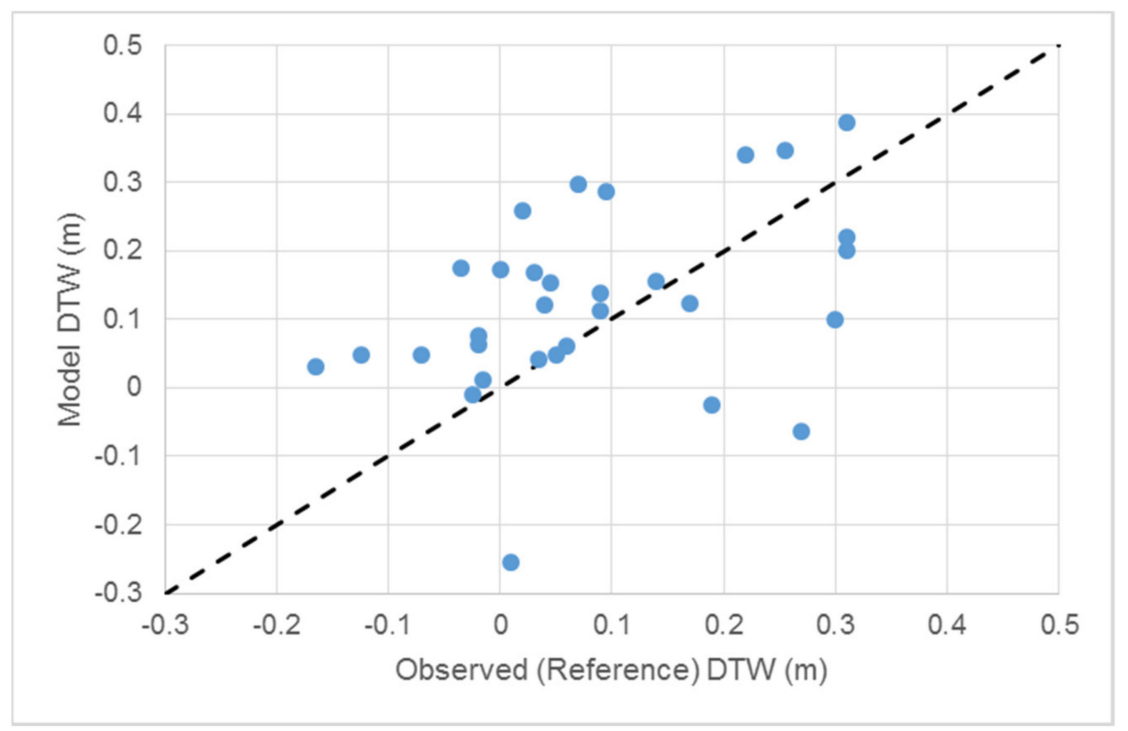

Figure 7. A scatterplot displaying the field measured depth to water (DTW) in $x$ axis and our model generated DTW in $y$ axis.

Table 1. Quantitative accuracy statistics for the predicted ground-water level and depth-to-water surfaces, based on 31 temporally coincident well measurements.

\begin{tabular}{ccccc}
\hline & $\begin{array}{c}\text { Minimum Absolute Error } \\
(\mathbf{c m})\end{array}$ & $\begin{array}{c}\text { Maximum Absolute Error } \\
(\mathbf{c m})\end{array}$ & $\begin{array}{c}\text { Root Mean Square Error } \\
(\mathbf{c m})\end{array}$ & $\begin{array}{c}\text { Mean Error } \\
(\mathbf{c m})\end{array}$ \\
\hline Ground Water Level & 0.6 & 50.5 & 22.0 & -0.9 \\
Depth to Water & 0.0 & 65.3 & 20.3 & -7.0 \\
\hline
\end{tabular}

\section{Spatial Distribution of Model Errors}

A spatial representation of model errors (Figure 8) reveals that most of the study area experiences relatively low absolute errors in the 0 to $20 \mathrm{~cm}$ range, with the larger errors $(50-70 \mathrm{~cm})$ limited to a few isolated hotspots. These hotspots (characterized by points 1 and 3 in Figure 8) coincide with upland patches within the study area (e.g., point 1), or densely treed wetland patches (e.g., point 3). In both cases, the issue revolves around errors in the DTM where the ground is occluded from vision. In the peatland areas, where terrain is generally visible to the sky (e.g., point 2), model errors are generally low. 


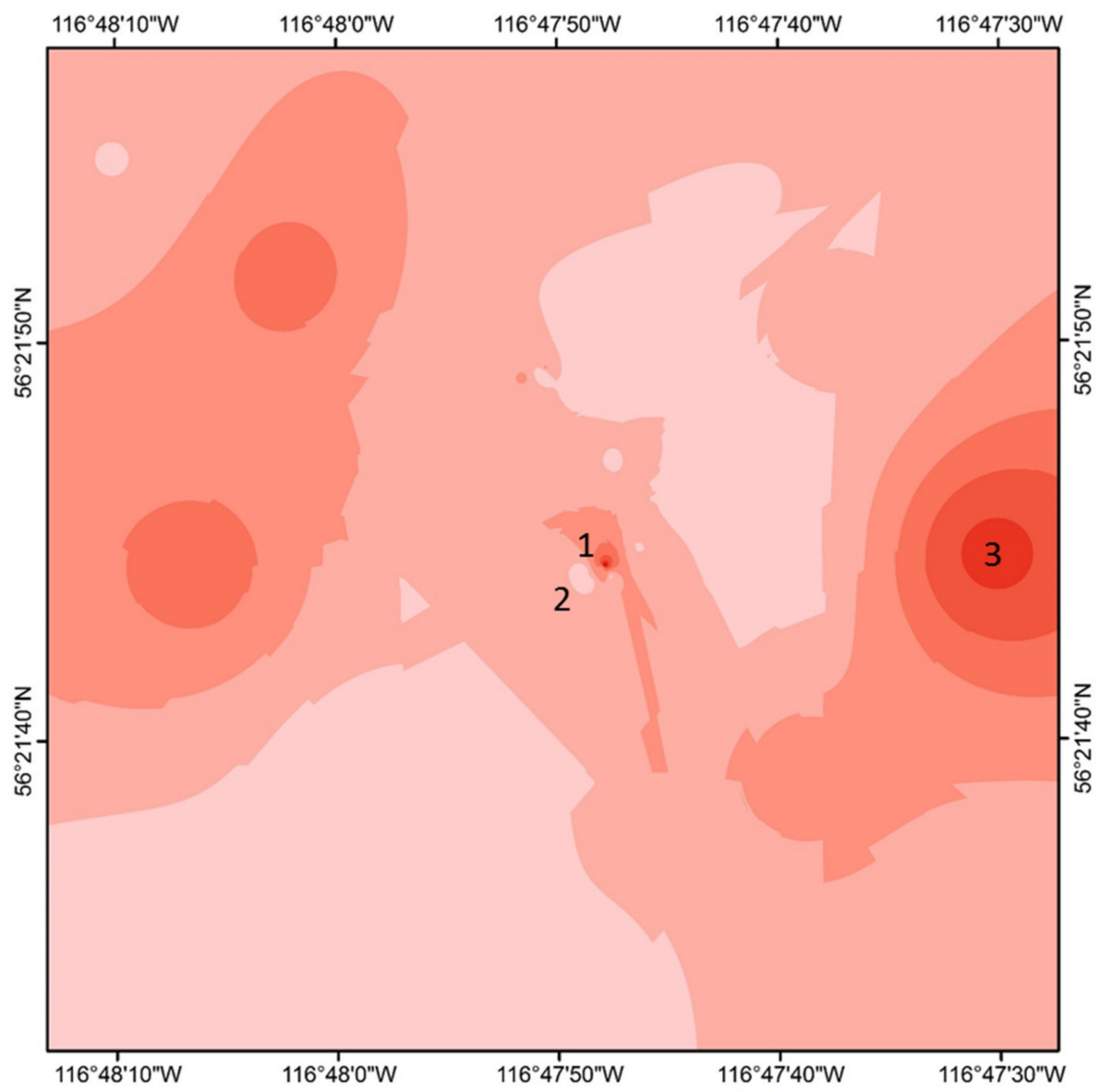

Model Absolute Error Distribution (cm)

\begin{tabular}{|l|l|}
$\square$ & $30-10$ \\
$\square$ & \\
$10-20$ & $40-50$ \\
& 40 \\
$20-30$ & $50-60$ \\
& $60-70$
\end{tabular}

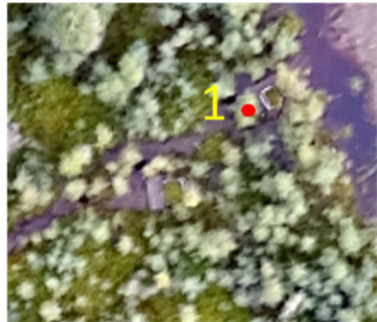

Point 1: DTM MSE: 0.613 DTWMSE: 0.653

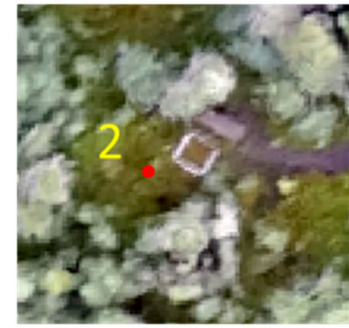

Point 2: DTM MSE: 0.013, DTWMSE: 0.022

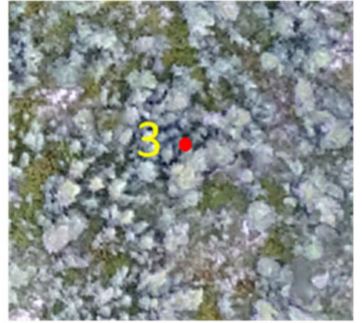

Point 3: DTM MSE: 0.835 , DTWMSE: 0.530

Figure 8. Visualization of the spatial distribution of (DTW) model errors, created by interpolating the absolute errors from 31 temporally coincident well measurements. Insets (bottom) show detailed visualizations of three well sites with relatively low (point 2) and high (points 1 and 3) observed errors.

\section{Discussion}

The predicted GWL surface matched temporally coincident field measurements closely in areas outside of dense vegetation. Our method performed worse in pockets of uplands within the study area, where extensive tree cover interfered with our ability to view and model terrain with passive photogrammetric techniques. These more complex pockets may also deviate from the assumptions 
of porous terrain and gently sloping water tables upon which this technique depends. Regardless, our interest is primarily within the less-vegetated peatlands, so we do not view this as a major shortcoming. The pattern of model accuracy varying inversely with vegetation density and surface complexity reflects the findings of Lovitt et al. [19] who modeled terrain in the same study area. Integrating high-density LiDAR data to the workflow might help to more accurately define terrain in challenging locations.

As DTW is an important driver of peatland ecosystem function, the ability to map it at ecosystem to watershed scales will be useful for monitoring peatland response to environmental change. An alteration of DTW of only 10-20 cm can have an important impact on peatland plant community type (e.g., [39]), carbon accumulation rate (e.g., [40]), and greenhouse gas exchange (e.g., [41]). Deep DTW also increases the susceptibility of peatlands to wildfire [42]. The impact of resource development across the boreal has also been shown to alter DTW in the range of $5 \mathrm{~cm}$ to $>1 \mathrm{~m}$, with clear impacts on ecosystem vegetation community and carbon exchange [43-45]. Across the majority of the open peatland areas of the study site, absolute error in DTW models was less than $20 \mathrm{~cm}$. This indicates that this technique is able to map DTW with an accuracy that is relevant to ecological function and impact of disturbance in peatlands, making it useful to monitor the impact of climate and land-use change over time.

Our approach depends on the availability of visible surface water, and can be expected to fail in areas where surface water is less common, or during times (after extended periods of drought, for example) when water tables are very low. Alternatively, at times when excess water is ponded on the surface-after a heavy rainfall, for example-in a manner that does not reflect general groundwater levels might also confound our workflow.

The extraction of reliable groundwater estimates requires that the estimated surface-water elevations are accurate. This could be difficult in situations where very clear water leads the generation of points from the bottom of shallow ponds rather than the surface. Alternatively, featureless water bodies may fail to generate photogrammetric points at all, limiting the usefulness of this approach. In our study area, turbid water and the presence of floating aquatic vegetation was helpful. In our experience, these conditions are typical of many peatlands, suggesting that our workflow might be broadly applicable.

Our technique demonstrates several advantages over traditional (ground based) methods of groundwater mapping, including:

(i) Our method does not require any field measurements to be able to generate groundwater surfaces,

(ii) If available, a large number of reference points can be used in the interpolation process that can lead to more accurate estimates, and

(iii) When compared to ground-based measurements, our workflow can be scaled across much larger study areas.

The RMSE of traditional approaches, as reported in the literature, range between 0.75 and $2.25 \mathrm{~m}[46,47]$, which is considerably greater than the errors that we have reported. However, it is clear that our method cannot completely replace ground-based techniques. For example, our workflow produces groundwater estimates at the time of image acquisition; new estimates would require new flights. Water-well monitoring, on the other hand, is much better suited for performing continuous or high-temporal-resolution measurements. Therefore, we characterize our workflow as a useful complement to traditional field-based monitoring techniques, and one that is particularly suited to upscaling.

\section{Conclusions}

Groundwater dynamics, commonly measured as GWL or DTW, are key factors in understanding hydrological processes and estimating GHG emissions in peatlands, and are commonly sought by researchers working in these ecosystems. The objective of this work was to develop and test a method 
for mapping groundwater using Earth-observation data acquired from a UAV. Our approach estimated both GWL and DTW to within $\sim 20 \mathrm{~cm}$ (RMSE) across a complex, 61-ha treed bog in northern Alberta, Canada. The largest errors were observed in pockets of densely treed upland areas and other areas where dense vegetation occluded terrain; areas of open peatland displayed considerably smaller errors. This novel approach offers great potential for measuring groundwater levels repeatedly over large areas, and can be expected to facilitate the development of spatially explicit models of GHG emissions, flow direction, and water accumulation in peatlands, and contribute insights into the impacts of disturbances on peatland hydrology and related ecosystem functions.

Acknowledgments: Research funding was provided by Emissions Reduction Alberta (Grant \# BI40020) and Shell Canada Ltd. We thank Shell Canada for site access and logistical support, and NAIT Boreal Research Institute and the University of Waterloo for assisting with project design and facilitating field-data collection. The authors declare no conflict of interest. The founding sponsors had no role in the design of the study; in the collection, analyses, or interpretation of data; in the writing of the manuscript, and in the decision to publish the results.

Author Contributions: Mir Mustafizur Rahman collected and processed the data, analyzed the results, wrote the paper, and is the main author of the article. Greg McDermid helped with ideas and technical advice during the data-collection and processing stages, and contributed to writing and reviewing the paper. Maria Strack helped in planning and executing field work, and assisted writing and editing the paper. Julie Lovitt contributed with data collection and data processing.

Conflicts of Interest: The authors declare no conflict of interest.

\section{References}

1. Wieder, R.K.; Vitt, D.H. (Eds.) Boreal Peatland Ecosystems; Springer Science \& Business Media: Berlin/Heidelberg, Germany, 2006; Volume 188, pp. 1-2.

2. Tarnocai, C.; Kettles, I.M.; Lacelle, B. Peatlands of Canada; Open File 6561 (Digital Database), CD-ROM; Geological Survey of Canada: Ottawa, ON, Canada, 2011.

3. Posa, M.R.; Wijedasa, L.S.; Corlett, R.T. Biodiversity and conservation of tropical peat swamp forests. BioScience 2011, 61, 49-57. [CrossRef]

4. Harris, A.; Bryant, R.G. A multi-scale remote sensing approach for monitoring northern peatland hydrology: Present possibilities and future challenges. J. Environ. Manag. 2009, 90, 2178-2188. [CrossRef] [PubMed]

5. Dinsmore, K.J.; Skiba, U.M.; Billett, M.F.; Rees, R.M. Effect of water table on greenhouse gas emissions from peatland mesocosms. Plant Soil 2009, 318, 229. [CrossRef]

6. Jungkunst, H.F.; Flessa, H.; Scherber, C.; Fiedler, S. Groundwater level controls $\mathrm{CO}_{2}, \mathrm{~N}_{2} \mathrm{O}$ and $\mathrm{CH}_{4}$ fluxes of three different hydromorphic soil types of a temperate forest ecosystem. Soil Biol. Biochem. 2008, 40, 2047-2054. [CrossRef]

7. Frolking, S.; Roulet, N.T.; Moore, T.R.; Lafleur, P.M.; Bubier, J.L.; Crill, P.M. Modeling seasonal to annual carbon balance of Mer Bleue Bog, Ontario, Canada. Glob. Biogeochem. Cycles 2002, 16, 4-1-4-21. [CrossRef]

8. Vazquez-Amabile, G.G.; Engel, B.A. Use of SWAT to compute groundwater table depth and streamflow in the Muscatatuck River watershed. Trans. ASAE 2005, 48, 991-1003. [CrossRef]

9. Lee, D.R.; Cherry, J.A. A field exercise on groundwater flow using seepage meters and mini-piezometers. J. Geol. Educ. 1979, 27, 6-10. [CrossRef]

10. Jha, M.K.; Chowdary, V.M.; Chowdhury, A. Groundwater assessment in Salboni Block, West Bengal (India) using remote sensing, geographical information system and multi-criteria decision analysis techniques. Hydrogeol. J. 2010, 18, 1713-1728. [CrossRef]

11. Walter, B.P.; Heimann, M.; Matthews, E. Modeling modern methane emissions from natural wetlands: 1. Model description and results. J. Geophys. Res. Atmos. 2001, 106, 34189-34206. [CrossRef]

12. Brunner, P.; Franssen, H.J.; Kgotlhang, L.; Bauer-Gottwein, P.; Kinzelbach, W. How can remote sensing contribute in groundwater modeling? Hydrogeol. J. 2007, 15, 5-18. [CrossRef]

13. Waters, P.; Greenbaum, D.; Smart, P.L.; Osmaston, H. Applications of remote sensing to groundwater hydrology. Remote Sens. Rev. 1990, 4, 223-264. [CrossRef]

14. Meingast, K.M.; Falkowski, M.J.; Kane, E.S.; Potvin, L.R.; Benscoter, B.W.; Smith, A.M.; Bourgeau-Chavez, L.L.; Miller, M.E. Spectral detection of near-surface moisture content and water-table position in northern peatland ecosystems. Remote Sens. Environ. 2014, 152, 536-546. [CrossRef] 
15. Takada, M.; Mishima, Y.; Natsume, S. Estimation of surface soil properties in peatland using ALOS/PALSAR. Landsc. Ecol. Eng. 2009, 5, 45-58. [CrossRef]

16. Zhang, Y.; Wegehenkel, M. Integration of MODIS data into a simple model for the spatial distributed simulation of soil water content and evapotranspiration. Remote Sens. Environ. 2006, 104, 393-408. [CrossRef]

17. Stromberg, J.C.; Tiller, R.; Richter, B. Effects of groundwater decline on riparian vegetation of semiarid regions: the San Pedro, Arizona. Ecol. Appl. 1996, 6, 113-131. [CrossRef]

18. Harris, A.; Bryant, R.G.; Baird, A.J. Detecting near-surface moisture stress in Sphagnum spp. Remote Sens. Environ. 2005, 97, 371-381. [CrossRef]

19. Lovitt, J.; Rahman, M.M.; McDermid, G.J. Assessing the Value of UAV Photogrammetry for Characterizing Terrain in Complex Peatlands. Remote Sens. 2017, 9, 715.

20. Foody, G.M. Status of land cover classification accuracy assessment. Remote Sens. Environ. 2002, 80, $185-201$. [CrossRef]

21. Ingram, H.A. Size and shape in raised mire ecosystems: A geophysical model. Nature 1982, 297, $300-303$. [CrossRef]

22. Nex, F.; Remondino, F. UAV for 3D mapping applications: A review. Appl. Geomat. 2014, 6, 1-5. [CrossRef]

23. Rosnell, T.; Honkavaara, E. Point cloud generation from aerial image data acquired by a quadrocopter type micro unmanned aerial vehicle and a digital still camera. Sensors 2012, 12, 453-480. [CrossRef] [PubMed]

24. Niethammer, U.; James, M.R.; Rothmund, S.; Travelletti, J.; Joswig, M. UAV-based remote sensing of the Super-Sauze landslide: Evaluation and results. Eng. Geol. 2012, 128, 2-11. [CrossRef]

25. Remondino, F.; Barazzetti, L.; Nex, F.; Scaioni, M.; Sarazzi, D. UAV photogrammetry for mapping and 3d modeling-current status and future perspectives. Int. Arch. Photogramm. Remote Sens. Spat. Inf. Sci. 2011, 38, C22. [CrossRef]

26. Hugenholtz, C.H.; Whitehead, K.; Brown, O.W.; Barchyn, T.E.; Moorman, B.J.; LeClair, A.; Riddell, K.; Hamilton, T. Geomorphological mapping with a small unmanned aircraft system (sUAS): Feature detection and accuracy assessment of a photogrammetrically-derived digital terrain model. Geomorphology 2013, 194, 16-24. [CrossRef]

27. Woodget, A.S.; Carbonneau, P.E.; Visser, F.; Maddock, I.P. Quantifying submerged fluvial topography using hyperspatial resolution UAS imagery and structure from motion photogrammetry. Earth Surf. Process. Landf. 2015, 40, 47-64. [CrossRef]

28. Vitt, D.H.; Halsey, L.A.; Bauer, I.E.; Campbell, C. Spatial and temporal trends in carbon storage of peatlands of continental western Canada through the Holocene. Can. J. Earth Sci. 2000, 37, 683-693. [CrossRef]

29. James, M.R.; Robson, S. Mitigating systematic error in topographic models derived from UAV and ground-based image networks. Earth Surf. Process. Landf. 2014, 39, 1413-1420. [CrossRef]

30. Jaud, M.; Passot, S.; LeBivic, R.; Delacourt, C.; Grandjean, P.; Le Dantec, N. Assessing the Accuracy of High Resolution Digital Surface Models Computed by PhotoScan ${ }^{\circledR}$ and MicMac ${ }^{\circledR}$ in Sub-Optimal Survey Conditions. Remote Sens. 2016, 8, 465. [CrossRef]

31. Benassi, F.; Dall'Asta, E.; Diotri, F.; Forlani, G.; Di Cella, U.M.; Roncella, R.; Santise, M. Testing accuracy and repeatability of UAV blocks oriented with GNSS-supported aerial triangulation. Remote Sens. 2017, 9, 172. [CrossRef]

32. Blaschke, T.; Hay, G.J.; Kelly, M.; Lang, S.; Hofmann, P.; Addink, E.; Feitosa, R.Q.; Van der Meer, F.; Van der Werff, H.; Van Coillie, F.; et al. Geographic object-based image analysis-towards a new paradigm. ISPRS J. Photogramm. Remote Sens. 2014, 87, 180-191. [CrossRef] [PubMed]

33. Rahman, M.M.; Hay, G.J.; Couloigner, I.; Hemachandran, B. Transforming Image-Objects into Multiscale Fields: A GEOBIA Approach to Mitigate Urban Microclimatic Variability within H-Res Thermal Infrared Airborne Flight-Lines. Remote Sens. 2014, 6, 9435-9457. [CrossRef]

34. Gnanachandrasamy, G.; Ramkumar, T.; Venkatramanan, S.; Vasudevan, S.; Chung, S.Y.; Bagyaraj, M. Accessing groundwater quality in lower part of Nagapattinam district, Southern India: Using hydrogeochemistry and GIS interpolation techniques. Appl. Water Sci. 2015, 5, 39-55. [CrossRef]

35. Selvam, S.; Manimaran, G.; Sivasubramanian, P.; Balasubramanian, N.; Seshunarayana, T. GIS-based evaluation of water quality index of groundwater resources around Tuticorin coastal city, South India. Environ. Earth Sci. 2014, 71, 2847-2867. [CrossRef] 
36. Yao, L.; Huo, Z.; Feng, S.; Mao, X.; Kang, S.; Chen, J.; Xu, J.; Steenhuis, T.S. Evaluation of spatial interpolation methods for groundwater level in an arid inland oasis, northwest China. Environ. Earth Sci. 2014, 71, 1911-1924. [CrossRef]

37. Laaha, G.; Skoien, J.O.; Bloschl, G. Spatial prediction on river networks: comparison of top-kriging with regional regression. Hydrol. Process. 2014, 28, 315-324. [CrossRef]

38. Sun, Y.; Kang, S.; Li, F.; Zhang, L. Comparison of interpolation methods for depth to groundwater and its temporal and spatial variations in the Minqin oasis of northwest China. Environ. Model. Softw. 2009, 24, 1163-1170. [CrossRef]

39. Weltzin, J.F.; Bridgham, S.D.; Pastor, J.; Chen, J.; Harth, C. Potential effects of warming and drying on peatland plant community composition. Glob. Chang. Biol. 2003, 9, 141-151. [CrossRef]

40. Charman, D.J.; Amesbury, M.J.; Hinchliffe, W.; Hughes, P.D.; Mallon, G.; Blake, W.H.; Daley, T.J.; Gallego-Sala, A.V.; Mauquoy, D. Drivers of Holocene peatland carbon accumulation across a climate gradient in northeastern North America. Quat. Sci. Rev. 2015, 121, 110-119. [CrossRef]

41. Turetsky, M.R.; Benscoter, B.; Page, S.; Rein, G.; Van Der Werf, G.R.; Watts, A. Global vulnerability of peatlands to fire and carbon loss. Nat. Geosci. 2015, 8, 11-14. [CrossRef]

42. Kettridge, N.; Turetsky, M.R.; Sherwood, J.H.; Thompson, D.K.; Miller, C.A.; Benscoter, B.W.; Flannigan, M.D.; Wotton, B.M.; Waddington, J.M. Moderate drop in water table increases peatland vulnerability to post-fire regime shift. Sci. Rep. 2015, 5, 8063. [CrossRef] [PubMed]

43. Chimner, R.A.; Pypker, T.G.; Hribljan, J.A.; Moore, P.A.; Waddington, J.M. Multi-decadal changes in water table levels alter peatland carbon cycling. Ecosystems 2017, 20, 1042-1057. [CrossRef]

44. Miller, C.A.; Benscoter, B.W.; Turetsky, M.R. The effect of long-term drying associated with experimental drainage and road construction on vegetation composition and productivity in boreal fens. Wetl Ecol. Manag. 2015, 23, 845-854. [CrossRef]

45. Strack, M.; Softa, D.; Bird, M.; Xu, B. Impact of winter roads on boreal peatland carbon exchange. Glob. Chang. Biol. 2017. [CrossRef] [PubMed]

46. Ahmadi, S.H.; Sedghamiz, A. Application and evaluation of kriging and cokriging methods on groundwater depth mapping. Environ. Monit. Assess. 2008, 138, 357-368. [CrossRef] [PubMed]

47. Buchanan, S.; Triantafilis, J. Mapping water table depth using geophysical and environmental variables. Groundwater 2009, 47, 80-96. [CrossRef] [PubMed] 